the variety of reasons and goals that gave birth to this fascinating series of frescoes.

JOHNNY L. BERTOLIO, University of Toronto

\title{
Quinlan-McGrath, Mary.
}

\section{Influences: Art, Optics, and Astrology in the Italian Renaissance.}

Chicago: University of Chicago Press, 2013. Pp. xi, $284+26$ ill. ISBN 978-0226-92284-3 (hardcover) \$35.

Mary Quinlan-McGrath, professor of art history, succinctly states in the opening pages that her book interrogates "why the learned believed in astrology and how art participated within its practices" (7). Over the next several hundred pages, she ambitiously attempts to investigate the importance of astrology as it pertains to astronomy and theology. Quinlan-McGrath structures her text around four basic points derived from Plato's Timaeus: the study of heavens as it relates to the work of a "single creator"; how the creator gave humans alone a share of the divine intelligence to allow them to see and understand cosmic patterns; the idea of vision as "the threshold for the study of the heavens," the latter capable of being rendered in the visual arts; and a consideration of how the study of the heavens related to spiritual and intellectual pursuits. Such a structuring allows Quinlan-McGrath to trace a clear and logical evolution of thought relating to the corollaries among theology, astronomy, and astrology, which she derives from the treatises of Plato, Vitruvius, Plotinus, St. Augustine, Marsilio Ficino, Ptolemy, Roger Bacon, Alberti, and al-Kindi.

To explore these themes, Influences is divided into eight chapters, each of which examines topics related to the history of astronomy and astrology, followed by tangential discussions of their effects on urbanism, their relevancy to Renaissance treatises, particularly Ficino's, and three painted Roman vaults: the Sala della Cosmografia (Palazzo Farnese, Rome), the astrological vault at the villa of Agostino Chigi (Rome), and the astrological vault of the Sala dei Pontefici (Vatican, Rome). Of these chapters, the last is the only one dedicated to art historical analyses. Despite the diversity of the chapters, each is divided into sections that outline the nuances among specific terms and their usages 
from ancient to Renaissance times. Although at times repetitive, the systematic approach allows the author to illustrate how even the most devout Christian intellectuals turned to astrology to inform their religious and political futures, even to the point of changing the date of their births or arguing for a different founding date of important Italian urban centres to correspond with more favourable horoscopes and astrological readings.

Despite the merits of Quinlan-McGrath's Influences, I would be remiss if I did not express my concerns about its structure and presentation. First, I found the scattered inclusion and references to Arabic astronomical and philosophical writers somewhat superficial, especially given the author's propensity to sound their accolades. Although Arabic intellectual practices were highly influential upon early modern engineers, scientists, artists, and the like, as the author rightly notes, their sporadic inclusion within Influences seems forced at times. This suggests a struggle for inclusivity and simultaneously highlights the restrictions of the topic. Indeed, Quinlan-McGrath is unable to explore the rational and religious significances of astronomy in Arabic traditions with the same legibility that emerges from her detailed examination of Italian culture. Nevertheless, the connections drawn are logical and highlight the known influences of Arabic writers despite the lack of cultural context.

Second, despite the book's catalogue designation (Fine Arts) and title, and the art historical value of the author's other published works, art was substantially lacking within Influences. The text could just as easily have stood alone-and probably should have-in the category of historical inquiry, without attempting art historical analysis. As a point of fact, approximately fifteen percent of the text is devoted to artistic works that at the outset were presented as being central to the book's argument. Discussions of the painted Roman vaults are isolated to the final twenty pages of the book's last chapter. Although much information about these wonderfully complex painted ceilings can be gleaned from canonical art historical surveys of Italian Renaissance art and architecture, the presentation of the visual content seems rushed and compressed. Quinlan-McGrath's formal descriptions and interpretive analyses of these paintings would have benefitted immensely from the inclusion of several drawings of the vaults. At the centre of book, among the "plates," the small colour reproductions are crisp; however, schematics of the paintings would offer much needed clarity to those not trained in Italian Renaissance visual culture. Similar issues abound in references to the numerous other black-and-white 
reproductions throughout the whole of the text, as little descriptive content is provided. In other words, a more sophisticated weaving of visual descriptors with the book's wonderful textual analyses would have benefitted the reader.

Aside from my concerns over the presentation of the book's visual data, the book is wonderful in its originality and the author's willingness to take on the tedious task of highlighting the subtlety of meaning in Italian Renaissance culture. For those interested in the nuances and complexities that existed among astronomy, astrology, and theology, Mary Quinlan-McGrath's Influences is a must read, with text rich in content and data.

C. CODy barteet, The University of Western Ontario

\section{Strier, Richard.}

\section{The Unrepentant Renaissance: From Petrarch to Shakespeare to Milton.}

Chicago: University of Chicago Press, 2011. Pp. xii, 304. ISBN 978-0-22677751-1 (hardcover) \$45.

Richard Strier's timely study proclaims itself as "a return to Burckhardt" and an alternative to the dour and repressed picture of the Renaissance proposed by Stephen Greenblatt's New Historicism, and its more recent inheritor, the "new humoralism" of Michael Schoenfeldt. Treating an impressive range of poets, playwrights, philosophers, and theologians from the fourteenth to the seventeenth century-including Petrarch, Luther, Ignatius, Erasmus, More, Shakespeare, Donne, Herbert, Montaigne, Descartes, and Milton-Strier argues that the authors he analyzes oppose (or do not accept as unassailable) the "Christian-Stoic-Platonic synthesis that produced the 'official' and, one might wrongly think, unquestioned values of the period" (2). In this sense, they are unabashedly "unrepentant." The chapters consider texts that reject the values and virtues of, in order, reason and the moderation of anger, the inferiority of the physical to the spiritual, ordinary decency and morality, the denial of materialism and worldliness, and the need for humility (1). Taking up where Burckhardt's Italian Renaissance individualism left off, Strier contends that the Reformation and Counter-Reformation contributed to the elevation of the ordinary layperson, and made possible expressions of "self-assertion, perversity, 